\title{
TOP-DRESSING IN SHEEP-FARMING ON ROLLING COUNTRY IN THE HASTINGS DISTRICT.
}

\author{
I. I. Ецготт, Assistant Instructor in Agriculture, Hastings.
}

OfFicial figures showing the amount of artificial fertilizer delivered at officered railway-stations in Hawke's Bay over the period 1928-29 to 1935-36 are as follows :-

\begin{tabular}{|c|c|c|c|c|c|c|}
\hline & \multicolumn{3}{|l|}{ Y̌ear. } & Tons. & $\begin{array}{l}\text { Decrease } \\
\text { relative to } \\
\text { I } 928 .\end{array}$ & $\begin{array}{l}\text { Increase or Decrease } \\
\text { relative to } 193 \mathrm{I}-32 \text {. }\end{array}$ \\
\hline $\operatorname{Ig} 28-20$ & . & . & . & 18,752 & Per Cent. & Per Cent. \\
\hline I929-30 & . . & & . & I3, 677 & 27 & $\ldots$ \\
\hline I930-3I & . . . & & $\therefore$ & I3, $88 \mathrm{~g}$ & 26 &, \\
\hline I $93 I-32$ & . & & . & 13,280 . & 20 & . \\
\hline I932-33 & . & & . & II , 899 & 36 & Io (decrease). \\
\hline I $933-34$ & . & 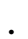 & . & $\mathrm{I} 3,80 \mathrm{~g}$ & 26 & 4 (increase). \\
\hline I $934-35$ & . & & . & I 8,757 & & 41 (increase). \\
\hline I $935-36$ & . & . & . & I 6,405 & & 23 (increase). \\
\hline
\end{tabular}

These figures indicate a steady decrease in the amount of fertilizer brought into Hawke's Bay from the peak year, I928-29 to I932-33, since when there has been a steady increase up to the present time.' It appears, therefore, that the amount of fertilizer brought into Hawke's Bay has strictly coincided with the prosperity of the community. That this is so is frequently borne out by farmers, who say that they usually top-dress but have not done so during the slump, although they have recommenced this season.

The indications from the farm-management survey at present being conducted by the Department of Agriculture in the area under discussion are that, in general, the amount of top-dressing done is relatively small. Of the total of about ninety farms so far visited, only one farm has been seen where the total area of the holding is top-dressed each year, although nost farmers interviewed agree that top-dressing gives good results and pays for its application. About to per cent. of the farmers visited do no top-dressing at all, while farms, on similar country around them, are at least receiving a certain amount. The reason advanced in nine cases out-of ten is not that manures do not give a response and pay for their application but that the farmer is not in a financially sound enough position to expend money in this direction.'

It seems that, with the increasing dissatisfaction with the rape -crops being obtained, due to attack from pests, there is a trend to the top-dressing of grassland and the growing of subterranean clover, :so that an increasing percentage of lambs may be turned away fat off the mothers. Many instances are on record where this has. already -taken place. 
In general, in the area under review, superphosphate is the only fertilizer applied. On some of the higher rainfall country basic slag is being used, but not commonly. Potash and nitrogen are practically never used, and lime is used by about 20 per cent. of the farmers.

The tendency is, on the lighter land and under rainfall conditions of over ' 35 in., to apply anything between I cwt. and 3 cwt. of fertilizer per acre. Fertilizers are nearly always applied in the autumn, usually about April.

'Method OF ApPLication.

Large areas of the district under discussion are suitable for topdressing through a manure-broadcaster, either drawn by horses or by tractor. Much of the country, however, is of such a nature that topdressing must be done by hand. The average area which can be topdressed by a distributor, on country over which the distributor can pass without much trouble, is Io acres to I2 acres per day. Areas top-dressed by hand vary between 7 acres and Io acres per man per day; depending on the rate at which the fertilizers is being applied and the nature of the country to be traversed.

\section{Experiences and Comparisons ON SELECTED Farms.}

EXAMPLE I.

Farm' A: Top-dressed ( 3 cwt. per acre on 350 acres) ; Farm B :. Untop-dressed.

Rainfall : Approximately $\mathbf{5 0}$ in. annually, with approximately $\mathbf{1 2 . 5}$ rainy days.

Farm $A$.-This property, I, I43 acres in area, was taken up eight years ago, and top-dressing was commenced in the following year. The place was largely covered with fern and scrub, which has had to be cleared and ploughed before good grasses could be sown. In its untopdressed state this type of country does not hold good grasses and clovers. for more than three or four years, when the pasture becomes invaded with brown-top, fern, and scrub. When the property was first taken over it carried 500 sheep. In 1928-29, when top-dressing was commenced, it carried 800 sheep, 500 of which were breeding-ewes, the balance hoggets. The average' lambing percentage at this time was 55 per cent. to 60 per cent. To-day, with the dearing and sowing-down and subdivision, I, I00 breeding-ewes are being carried, with an average lambing from the ewes of 85 per cent. to 90 per cent. So far no change-over from breeding to fattening has taken place, as stock numbers are steadily increasing and the surplus ewe lambs are required each year to supplement the -ewe flock. It is anticipated from results so far obtained that three ewes per acre will be carried and surplus lambs fattened. It has been calculated that, over the eight-year period, an increase of $3 \mathrm{lb}$. of wool per head has been obtained, and the quality greatly improved.

Pastures which have been down for' six or seven years show no. deterioration, the paddocks tending to improve rather than to degenerate, as was the case before top-dressing was commenced. Increased consolidation and fertility owing to higher stock numbers contribute to this. Manure always is sown with the seed to give the young plants a good start-a thing which one feels is not common enough in Hawke's Bay, where a fairly late sowing is usually made after rape. 
Farm B.-This farm, I,595 acres in area, is probably better land than Farm A, although it is harder to work in that much of the country is unploughable and would have to be top-dressed by hand. This property, on the 1, 600 acres, was carrying in I035 1,070 sheep, a decrease steadily taking place after I925, when $\mathbf{1 , 4 0 0}$ sheep were carried. Lambing percentages range from 70 per cent. to 80 per cent. Wool clip averages $7 \mathrm{lb}$. per head. No top-dressing is done at all.

Comparison.-Farm A is carrying 1, 600 sheep on I,I43 acres, showing an advance in eight years of I, Ioo sheep. Practically the whole of these sheep are being carried on the top-dressed portion of the farm, which represents only 350 acres out of a total of 1,100 , or approximately onethird.

Farm B is carrying 1, 070 sheep on I,595 acres, and stock numbers have, over a ten-year period, remained approximately constant., with a slight tendency to decrease. Farm $A$ has an average lambing percentage of 85 per cent. to go per cent. ; farm B, one of 70 per cent. to 80 per cent. Farm A clips g lb. of wool per head; farm B, $7 \mathrm{lb}$.

EXAMPLE 2 .

Farm A : Top-dressed (I $\frac{1}{4}$ cwt. per acre on 800 acres). Farm B : Untop-dressed. days.

Rainfall : 35 in. annually, with an average of 112 to 125 rainy

In this case, no farm can be found that is sufficiently like it in size and condition, to warrant any comparison being made, but country essentially similar to that which is being top-dressed is carrying half to three-quarters of a sheep per acre at the present time.

On this property, which is 2,430 acres in area, having $\mathbf{1}, 300$ acres of flat land, previous to the top-dressing, subdivision, and the planting of shelter-belts all wet sheep were carried entirely on the hill country, the flats carrying wethers and hoggets only. The flats were subdivided into three sections-640 acres, 400 acres, and 250 acres in area. This total area has since been further subdivided into fourteen paddocks. On I.50 acres of the 640-acre section only 200 wcthers were carried, and in another block, 250 acres in extent, 260 very late lambing and empty ewes were run from January to May. This section was ploughed out of gorse and scrub eighteen years ago, and little subdivision and no top-dressing has been done. In all the other paddocks of the flat land, which have been reduced in size by fencing and sheltered as well as top-dressed, three to five ewes can be run from July to January and cattle in the spring, and cattle and ewes while the rams are out, from the beginning of $M$ arch 'to the end of- April: From- the-end -of -April to' the end- -of- July- the" paddocks are grazed with hoggets.

On the farm as a whole, before the improvements mentioned took place; I,000 ewes and 1,500 dry sheep, made up of $\mathbf{I}, 000$ hoggets and 500 wethers, were carried. This has increased to 3,100 breedingewes, I00 wether lambs, 1,120 hoggets, and 85 rams. Cattle numbers have greatly increased. The farmer has therefore increased the carrying of the whole farm by seven-eighths of a breeding-ewe to the acre plus dry sheep and cattle. 
In both quality and quantity the wool has shown a steady improvement.

EXAMPLE 3.

-Farm A-: Top-dressed (3 cwt. per acre on zoo acres) ; Farm B : Untop-dressed.

Kainfall : 60 in. annually, with between 125 and I50 rainy days.

The two properties chosen in this district are on exactly the same type of country, of almost the. same area, and with the similar areas' of ploughable land.

Farm A --This property has been top-dressed fairly heavilv and consistently for the last six years. Farm B has had some,' topdressing. but very little. Farm A was taken up in I926, and was then carrying 600 to 700 ewes, and the" balance, making a total of I,466, were hoggcts and dry ewes. At the commencement of top-dressing in I930, I,000 ewes were' carried, and no dry sheep" except twenty or thirty killers and rams. The change-over from hrecding to buying was made as soon as the property. was taken over in I026. Up to and including I930, an average of 40 per cent. of lambs 'went away fat off. the mothers, the balance being sold as stores. To-day, 75 per cent. of the lambs go. away fat off the mothers, 60 per cent. going in the first cut, :the balance being fattened on grass, no rape being grown. In addition to the lambs which are bred on the place and fattened, between 400 and 500 stores are bought in and fattened. To-day the property is carrying approximately 1,400 ewes and fattening lambs on the 682 acres. Old ewes are sold in lamb, and all 'cattle are sold fat.

There is also a marked difference-which, however, cannot be indicated definitely-in the way that the ewes come out of the wool : nearly every sheep shorn is prime enough for killing off the shears. Whereas lambs previously were not turned off the place until the end of December the first draft now goes away at the end of November., Ewes coming from nearly anywhere on to this place seem to do well, coming through the winter to lambing in much better condition than was the : case previously. This has been so noticeable that as the result of top-dressing it has been found possible on this farm to discontinue the growing of swedes to carry ewes through the winter.

Farm B, which has not been top-dressed. This property* was taken over in 1925 by the present owner, and carried, on the 625 acres, I, Ioo sheep, and this' number has remained approximately constant until this year, when it is again I,I00 sheep-800 breedingewes, 260 hoggets, 40 killers, rams, \&c. The Southdown is not used at all, and wether lambs are not fattened, but are sold as stores. Old ewes at five years old and cull two-tooths are sold as breedingewes. If one breeding-ewe is estimated as the equivalent of two dry 'sheep the farm carries approximately' 950 breeding-ewes. : The amount. of wool clipped on this place, where' there is scope for the breeding and selection of well-woolled sheep, was $9.5 \mathrm{lb}$.' $^{\prime}$ per head. The lambing percentage is 95 to ioo. It -must be remembered that only ithe Romney : ram is being issed, and there is a percentage'of two-tooths in the flock. 
Comparison.-Farm A has increased from 1,400 sheep, 600 to 700 of which were breeding-ewes, to I,000 ewes in I930, when topdressing was commenced, to $I, 400$ at the present time. Farm 'B has remained stationary at I,I00 sheep, say, equivalent to 950 breedingewes, since 1925.

Farm $A$ has an average lambing percentage of ro5 to 114. Farm $B$ has an average lambing percentage of 95 to 100 , onequarter of the flock being two-tooths, and the Romney instead. of the Southdown ram being used.

Farm A clipped Ir.3 lb. of wool this year. Farm B clipped $9.5 \mathrm{lb}$.

Farm A sells all fats ; Farm B sells all stores.

EXAMPLE 4.

Färm A : Top-dressed (I cwt. of superphosphate per 'acre every other year on 200 acres) ; Farm. B: Untop-dressed.

Rainfall : 35 in. to 40 in., with 125 rainy days.

Farm A.-This property is 443 acres in extent, and was taken over by the present owner in I92I, when it carried 370 sheep, 90 of which were hoggets. When top-dressing was commenced eight or nine years ago, 450 ewes and I00 ewe hoggets were being carried, and swedes and rape grown for winter and fattening feeds respectively, which meant the upkeep of a team and implements. The change-over from the policy of breeding to buying was made simultaneously with the commencement of top-dressing. To-day the property is carrying over 800 ewes. Since the top-dressing of the farm the lambing percentage has increased from 85 to IIo, the 85 per cent. being the average lambing obtained from the Romney 'flock before the change-over to the Southdown was made and top-dressing was applied. It is maintained by the owner that since top-dressing he has increased by $3 \mathrm{lb}$. the weight of wool per fleece.

The year the change-over to the 'Southdown ram was made only 20 per cent. of lambs went away off the mother, and this was. usual up to that time. In the autumn of that year fertilizer was applied, and the following season 70 per cent. of the lambs went away off the mothers, increasing up to go per cent. in the following year. Since that time practically every lamb : on the place goes away fat off the mother.

The wool clip averages $8 \mathrm{l} \mathrm{lb}$. to $8 \frac{1}{2} \mathrm{lb}$. per fleece. When rape was grown as a fattener, lambs never went away until February or March, but now all lambs are away before the end of January.

Farm B.-In 1922 this place carried through the winter 533 sheep on the 380 acres. The present number being carried is 674,550 of -which -are ewes and 120 hoggets-- -There -has, therefore, been an advance in total sheep numbers of $123^{\prime}$ in the last fourteen years. The wool clipped per fleece on this property is $6 \mathrm{lb}$. to $7 \mathrm{lb}$. The lambing percentage is. 80 to 85 , the Romney ram being used, and there being about onefifth of the flock two-tooths.'

Comparison.-Farm A has shown an advance of 546 sheep on an original number of 370 , together with a change-over to fattening,. over a fifțeen-year period. 
. Farm B over the same period has shown an advance of 123 sheep over an original 533, unaccompanied by any change to fattening.

Farm A clips $8 \mathrm{lb}$. to $8 \frac{1}{2} \mathrm{lb}$. per head off old sheep. Farm B clips $6 \mathrm{lb}$. to $7 \mathrm{lb}$. per head off a mixed flock.

Farm A has an average lambing of over Ioo per cent., and lambs go away fat off the mothers. Farm $B$ has an average lambing of 80 per cent. to 85 per cent., and no lambs are fattened.

\section{DisCUSSION,}

The field experience described above is not submitted as definite proof that top-dressing pays in all the areas mentioned above, although the figures certainly suggest that this is the case; Neither are the. results described to be interpreted necessarily as a condemnation of the practice of those farmers who do not top-dress, for many farmers who took over places in high-price periods were not in the position during the slump years to spend money on fertilizers.

The data presented tend to show that, as a result of top-dressing- (I) Stock numbers, on all places quoted above as being top-dressed, have increased :

(2) In most cases this increase has been, or will be, accompanied, by a change-over from the selling of the surplus stock as stores to the selling as fats :

(3) That lambing percentages tend to increase :

(4) That more wool per fleece, of a better quality, is grown :

(5) That good pastures can be maintained in places where good pastures were never maintained before.

It is rather noticeable that all places chosen were in areas with a rainfall of $35 \mathrm{in.} \mathrm{or} \mathrm{more.} \mathrm{The} \mathrm{results} \mathrm{cited} \mathrm{above} \mathrm{were} \mathrm{not} \mathrm{the} \mathrm{results}$ of top-dressing alone; they were the results of a combination of factors of which top-dressing was one. In order that maximum results may be obtained from the application of fertilizer, the value of efficient management of pastures and stock, subdivision, and shelter must be appreciated, and, in the cases where good results have been obtained from top-dressing, these matters have received, due attention.

\section{- Discussion.}

Mr. McGillivray: There have been some most remarkable results from top-dressing in parts of Canterbury on country that is not quite comparable with the country mentioned by Mr. Elliott. The country I refer to has a rainfall ranging from 24 in. to 28 in. Top-dressing was carried out for a good many years, but results from superphosphate alone in almost all cases were found to be rather unsatisfactory. Since quite a number of the farmers have been using lime in addition to superphosphate results have been very good. The average runholder was rather slow in using lime because of transport difficulties, which now seem to have been overcome. There were also difficulties which have been overcome, in regard to the distribution of the lime and of fertilizer. Very few lambs were fattened off their mothers prior to topdressing, and now the greater number of them are. The increase in top-dressing has been quite remarkable, and the net income has been greatly increased.

Mr. Connell : The subject-matter of the paper is of primary importance to central Hawke's Bay. The figures given by Mr. Elliott as to manuring in Hawke's Bay imply that more manure is being used in central Hawke's Bay than is actually the case. A substantial proportion of-the total amount used in Hawke's Bay is used in southern Hawke's Bay south from Takapau, and another portion of it is used in central Hawke's Bay in dairying and in crcpping, and when you deduct those portions of the total of 16,000 tons for the whole 
of Hawke's Ray there is relatively 'little used in sheep-farming in "central Hawke's Bay. We know from considerable work in different parts of New Zealand that top-dressing, by itself increases rather than lessens the gap in the absolute difference between the peak of- top production and the peak of low production. That top-dressing increases the difference between low and high production is one of the reasons why it has not expanded more in Hawkc's Bay. Another aspect is that top-dressing by itself would make the difficulty of a drought year more acute than over, and in this particular district we hear a great deal about the difficulties of the droughts. These two aspects of the matter seem to me to raise the question of whether top-dressing, if it is going to become more general in Hawke's Bay, should not be accompanied by a change in the farming, which would involve more special-feed provision. I do not know just how this provision should be made, but it probably should be along the lines of sowing more lucerne, more silage, and possibly more specia arable annual crops. Another interesting feature of the paper is this : that the farms cited by Mr. Elliott are of a rainfall of 35 in. or more. The general impression seems to be that this is typical only of a small portion of central Hawke's Bay, but, on the other hand, the figures of the Meteorological Service show that that rainfall characterizes almost the whole of central Hawke's Ray. This 35 in. rainfall becomes of particular interest in view of the good results being obtainct in Canterbury with a 25 in. rainfall or. thereabouts. There seem to be great possibilities for top-dressing in Hawke's Bay, but the position is not as simple as it might scem on the surface; it is extremely difficult to disentangle the effects of several changes that have taken place on the farms cited. A great deal of investigation has still to be done before we

know whether the indications of the paper are generally applicable .in practice It seems that if sheep-farming of that portion of Hawke's Ray under consideration is to make advancement top-dressing will be the basis of good results, and other measures will be needed to assist it.

Professor Peren : The man working with a rainfall of from $30 \mathrm{in}$. to 35 in. and droughts is up against a more difficult proposition than the man working with a rainfall of $25 \mathrm{in}$. and droughts.

$M r$. Webster : This paper raises the question how far top-dressing may be economic on some of these pastures, and how far one should employ any alternative means of supplying the additional phosphate which the stock require-e.g., mineral licks.

Mr. Flay: The increases on those farms cited were quite outstanding, and balance-sheets for those farms to-day under normal conditions would show that top-dressing unquestionably was financially advantageous. It is the lag in topdressing which is one of the reasons for farmers not being enthusiastic in general adoption of it. There might be another reason-viz., that of the education of the farmer who is handling this country. There may be still another reason, and that is that those farmers who do not top-dress have not sufficient working capital : top-dressing would mean increasing overdrafts rather than increasing net returns in the first few years. Therefore those people have to go slowly. On the other hand, the farmers who do not top-dress may be so financial that they are quite content and do not need to top-dress.

Mr. Cockayne: One feels that Mr. Webster has brought up an extremely important point. It seems to me that one of the essential features of increased production of the country being considered is more adequate finance. 